IRA-International Journal of Management \& Social Sciences

ISSN 2455-2267; Vol.07, Issue 02 (2017)

Pg. no. 208-212

Institute of Research Advances

http://research-advances.org/index.php/RAJMSS

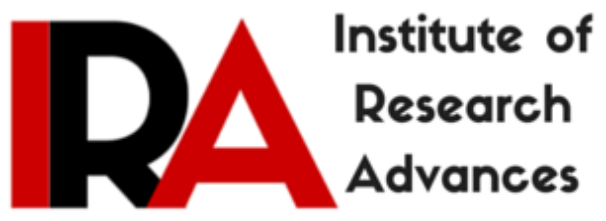

\title{
Lightning Risk: An Under-Valued Disaster?
}

\section{${ }^{1}$ Dr. Salini K}

Assistant Professor, P G Department of Commerce and Research Centre, Vimala College, (Autonomous), Thrissur. Affiliated to the University of Calicut, Kerala, India.

Type of Review: Peer Reviewed.

DOI: http://dx.doi.org/10.21013/jmss.v7.n2.p10

\section{How to cite this paper:}

K, Salini. (2017). Lightning Risk: An Under-Valued Disaster?. IRA-International Journal of Management \& Social Sciences (ISSN 2455-2267), 7(2), 208-212.

doi:http://dx.doi.org/10.21013/jmss.v7.n2.p10

(C) Institute of Research Advances

(cc) EY-NC

This work is licensed under a Creative Commons Attribution-Non Commercial 4.0 International License subject to proper citation to the publication source of the work.

Disclaimer: The scholarly papers as reviewed and published by the Institute of Research Advances (IRA) are the views and opinions of their respective authors and are not the views or opinions of the IRA. The IRA disclaims of any harm or loss caused due to the published content to any party. 


\begin{abstract}
Lightning is a very common natural phenomenon which primarily solicits little attention. In this climate allied innate localized activity, high electric charges are generated which cause disastrous outcomes, both physically and economically. Many lives are burnt and severe losses are suffered due to this natural disaster. But, it is often doubted that the deaths and economic losses due to lightening are under reported. Many reasons are cited as difficult in getting authentic figures, inadequacy of the government rules in the reporting areas etc. Disaster relief is also outside the sphere of such calamity. Comparison between the loss figures due to lightning with other disaster loss figures also reveals that the former ranks higher than the latter. Still, many of the lightning disasters are not properly accounted and recompensed by National Calamity and Relief Fund or any other such Relief Funds. The article is an attempt to see the depth of such an issue and major challenges faced by the victims to get the compensation from the authorities. Also, suggestions are sought to arrive at a satisfying solution to such an unnoticed problem.
\end{abstract}

Key Words: lightening risk, lightning injury, natural disaster, disaster management, calamity

\title{
1. Introduction
}

Lightning is highly a natural phenomenon. Scientifically speaking, lightning is a visible discharge of static electricity with a cloud or between clouds. It is a sudden expulsion of high voltage electricity in the sky from the positively charged upper part of a cloud to the negatively charged lower part. The lightning can be divided into intra-cloud, inter-cloud and cloud to ground types. Among these types, cloud to ground type is most disastrous. It is calculated that about 50,000 thunderstorms and 8 million lightning flashes occur worldwide every year. About eight flashes of lightning occur every second around the world (Allaby 2003). The peak discharge current in each stroke varies from several thousand amperes to 2,00,000 amperes or more and its passage is severely damaging to humans, trees, electrical structures, and other living and non-living objects (Illiyas, et.al, 2014).

Though taken very light, the magnitude of lightning disaster is very massive as it causes more than 2000 deaths every year in India (Vaddadi and Ramella, 2015). The historical data also adds that, the fatality figures of five major natural disasters for the period 1967 -2012 give confirmed evidence that lightning is the most damaging natural disaster in India. The High Powered Committee on Disaster Management $(\mathrm{HPC})^{1}$ had identified thirty odd dangerous disasters and thunder and lightning was one among the list. As per the report published by BIS (National Standard Body of India), none of the states in India is free from the risks and effects of thunder and lightning (BIS, 2007). Thunder and lightning occur in different time periods in different parts of the country. Usually, thunderstorm takes place during pre-monsoon periods i.e., March to May in an year. But some other parts of the country have the occurrence of lightning with thunder during monsoon season - i.e, June to September. It is more important to consider the thunderstorms occur in association with cyclical storms and depressions which happen during post monsoon season - i.e., October and November. Lightning also causes other convective phenomena called 'tornado', which are highly dangerous. When thunderstorms occur all over India, the most probable regions of tornado occurrence are Assam and adjoining regions, West Bengal, Orissa, Gangetic plains, Punjab and Haryana.

\section{Historical Perspectives of Lightning occurrences in India}

According to National Crime Records Bureau (NCRB) data, details of the emergencies happened due to five major disasters were only recorded during the period from1967 - 1970 namely, flood, landslide, cold stroke, heat stroke and lightning. All other causalities were categorized under 'miscellaneous' category.

\footnotetext{
${ }^{1}$ The High Powered Committee on Disaster Management (HPC) is constituted in August 1999, with an aim towards a systematic, comprehensive and holistic approach towards disasters.
} 
Even the historical records showed that lightning fatality figures positioned higher than the other disasters. This explains the critical information that the lightning disasters and its effects have been prominent in India since 1960s with more than 1,000 fatalities annually. It can be observed from the fatality figures of five natural calamities from 1967 -1970 that, other than lightning, causality figures for all other disasters were below 1,000 per annum. The damage due to lightning was continued to be the most life taking danger for a 24 year period except in 1993 and 1997. A series of major landslides in the Himalayan ranges in 1993 and the super cyclone in 1977 in Andhra Pradesh caused rises in casualties. During this period, the casualty figures for lightning ranged from 1,163 to 2,177, which was higher than that of any other disaster in India. There were certain accidents like landslides in Himalayas (1993), super cyclone in Andhra Pradesh (1977) and disha (1999), massive earthquake in Gujarat (13000 deaths in 26 January, 2001), floods in north and north-eastern parts of India (2000) which overtook the causality figures caused by lightning. Keeping apart these specific calamities, lightning induced disasters stood prominent during the 17 year period (1995 -2012). The major calamities together have caused 1,94,745 deaths and its break up in percent is given below (Table 1)

Table 1: Fatality Figures of Five Major Disasters for the 45 year period (1967 -2012)

\begin{tabular}{|c|l|c|c|c|}
\hline Sl.No. & \multicolumn{1}{|c|}{ Natural Calamity } & $\begin{array}{c}\text { \% to total } \\
(1,94,745 \text { deaths })\end{array}$ & $\begin{array}{c}\text { Average Annual } \\
\text { Mortality }\end{array}$ & Rank \\
\hline $\mathbf{1}$ & Lightning & $\mathbf{3 9}$ & $\mathbf{1 7 5 5}$ & $\mathbf{1}$ \\
\hline 2 & Flood & 18 & 795 & 2 \\
\hline 3 & Landslide & 15 & 670 & 3 \\
\hline 4 & Heat stroke & 15 & 673 & 3 \\
\hline 5 & Cold stroke & 13 & 573 & 4 \\
\hline
\end{tabular}

Source : Compiled by the author (database taken from NCRB)

\section{The Kerala Context of Lightning Risk}

Kerala ranks high among Indian States that suffer a substantial loss of lives in lightning strikes every year, according to the Atmospheric Science Division of the Centre for Earth Science Studies (CESS) in Thiruvananthapuram. A study commissioned by the Union Ministry of Home Affairs to see the level of risk from lightning in Kerala. On an average 71 people die and 112 people get injured per annum in Kerala. Lightning in Kerala seems to be caused by thermal or clouds and occurs at most of the time (83\% of the total) in the late afternoons. The reason is the combination of conductive weather patterns, topography features and tall coconut trees. In general, mid lands of Kerala are more affected than the coastal plains and high lands. Western Ghats seem to have some influence in lightning occurrence in Kerala. However, over mountains the incidence is low. Majority of personnel injury seems happen due to ground conduction of lightning. Due to high vegetation density in Kerala, the lightning conductor seems to be ineffective.

But getting authentic figures regarding the deaths and loss due to lightning and thunder is difficult. The chance of under-reporting by the media of the same is highlighted. The reason could be deaths due to lightning is mostly single events and only in some few cases group events are happened making the disaster unattractive to the media. Lightning does not find a place in accounts of extreme weather calamities in India. Reporting of such events are not made mandatory by the Government either at Central or State level. Medical reports on such matters are the only official records which cannot always be considered as highly reliable and straight (Cooper and Kadir, 2010). Despite its proneness to lightning fatalities, India does not have a lightning detection network. It was only in 2012 that the India meteorological department initiated steps to establish one to locate inter-cloud, intra-cloud and cloud-toground lightning (IMD 2012). 


\section{Compensation Concerns to Lightning Risk}

The growing importance of lightning risk is evident from Table 1 above. But it is suspected whether the administrative set up at the government level has given due importance to lightning victims or not in terms of compensation. It always remained as an underestimated disaster.

The financial assistance in the wake of natural disasters is provided through the schemes of calamity relief fund (CRF) and national calamity contingency fund (NCCF) formulated by the Ministry of Finance based on the recommendations of successive finance commissions of India (Ministry of Home Affairs 2008). The CRF is made available to the states in advance every year to meet the expenditure for providing immediate relief to victims for a range of specified calamities approved by the Finance Commission, while the NCCF is a national fund to assist the states when the disaster loss goes beyond the CRF of the states.

Ever since the natural calamity compensation process was initiated in India, lightning was not included as a natural calamity due to the underestimated death, injury and damage figures. The high powered committee (HPC) on disaster management constituted by Government of India in 1999 to suggest institutional reforms and to evolve a systematic and holistic approach to disaster management has identified thunder and lightning as disasters under the water and climate-related disaster group (High Powered Committee on Disaster Management 2001). The HPC has also recommended the constitution of an expert committee to review the list of items approved for incurring expenditure from the CRF. However the recommendations have not materialized while reconstituting the CRF.

As lightning does not come under the guidelines of calamity relief rules, most of the lightning- affected states in India provide an ex-gratia amount of Rs one lakh to the kith and kin of the deceased person from the Chief Minister's Relief Fund (CMRF), also known as Chief Minister's

Distress Relief Fund (CMDRF) insome states of India. CMRF has states specific guidelines to help families suffering from chronic ailments (like cancer, cardiac issues, kidney transplant, brain tumor, etc), any natural or man-made calamities or accidents and a part of it is mobilized through public contribute. The families of the seven who died in the September 2013 lightning incidents in Guntur in Andhra Pradesh were paid compensation from the Apathbandhu Scheme. The government has implemented the scheme by paying a premium of Rs 24.39 crore to the insurance companythe New India Assurance Company for minimum coverage of 6,000 cases at Rs 50,000 per case (The Hindu 2011; Government of Andhra Pradesh 2012).Inclusion of lightning in the list of natural calamities under calamity reliefrules may be a good step to enable them states to utilize CRF for relief distribution and immediate assistance to the bereaved families. The Fourteenth Finance Commission constituted on 2 January 2013 has set financing of disaster management as one of the terms of reference to make recommendations for the period of 2015to 2020 (Finance Commission of India2013). The commission while reviewing the present arrangements of disaster-related financing may consider the gravity of lightning casualty to revise the modalities of disaster-related funds to enable compensation process. Economic damage due to lightning is another area to be studied further as lightning causes damages worth billions of rupees in the housing, agriculture, industrial and public sectors. The current financial allocation and mitigation measures in India are to be scaled up with site-specific risk reduction measures like technological interventions along with public awareness to cope with the present ominous lightning scenario of the country. The cost incurred by governments on insurance is large and in South Africa insurance claims due to lightning amount to more than R500 million per year (Gijben 2012). In the United States 30\% of electric failures are due to lightning and it also causes property damage resulting billions of dollars of insurance claims (Uman 2008). IBM Germany has shown that 4.8 days after an Electronic Data Processing system breakdown following lightning strikes, almost no firms will be able to operate (Cooray 2010).Research on lightning and its aftermath has been sporadic in India, and there is an urgent need for the government to intervene technologically, financially and also on a humanitarian basis. 


\section{Conclusion}

Lightning-associated fatalities and losses, a widespread disaster in India has received little attention probably because of the under-reporting of incidents and lower media coverage. Since there is no national database or platform to bring out the lightning fatalities and economic damage to the limelight within the administration and disaster management set-up of the country, lightning is considered as an undervalued disaster or persona non grata in the disaster setup in India. It is hoped this study will stimulate a serious debate over the neglected dimensions of disaster compensation acts and rules especially related to lightning. There is an urgent need for reorientation of perceptions on disaster insurance and government funding and it is hoped that lightning and its victims receive due attention and mitigatory relief from the governments.

\section{References}

1. Srinivas Vaddadi *1, VikramVardhan Remella1, Radha Srinivas Vaddadi, "Dermatological manifestation of lightning injury: A Case report", Amercian Journal of Medical Sciences, Vol. 2, No.1, pp. 30-33

2. Allaby, M (2003): Floods, Dangerous Weather Series (New York: Facts on File Science Library), 50

3. Illiyas, Faisel et.al, "Lightning Risk in India: Challenges in Disaster Compensation", Economic and Political Weekly, Vol. XLIX, No.23, pp. 23-27

4. Cooper, M A and M Z A Kadir (2010): "Lightning Injury Continues To Be a Public Health Threat Internationally", 21st International Lightning Detection Conference, 19-20 April, Orlando, USA.

5. IMD (2012): Expression of Information on Lightning Detection and Ranging Network, India Meteorological Department:5, viewed on 22 July 2013 (http://www.imd.gov.in/doc/LIGHTNG.pdf).

6. The Article of Hindu-Lightning Inflicts on Kerala Online Edition of India's National Newspaper Friday, Nov 16, 2007.

7. The Article of Hindu-Property Plus Kochi-The Science and Business of Protection from Lightning Online Edition of India's National Newspaper, Saturday, May 06, 2006. 